\title{
Contribution of Agro-Morphological Traits in Seed Yield of Indian mustard (Brassica juncea L. Czern \& Coss) Germplasm under Rainfed Condition
}

\author{
Ravindra Singh Solanki ${ }^{1 *}$, Pawan Kumar ${ }^{2}$, S.P. Mishra ${ }^{1}$ and S.R. Ramgiry ${ }^{2}$ \\ ${ }^{1}$ Mahatma Gandhi Gramodaya Chitrakoot Vishwa Vidyalaya, Chitrakoor, Satna (M.P.), India \\ ${ }^{2}$ R.V.S.K.V.V. (Rajmata Vijayaraje Scindia Krishi Vishwa Vidyalaya) Gwalior-474002, India \\ *Corresponding author
}

\section{A B S T R A C T}

The present experiment was conducted in on 220 cultivars of mustard to measure the correlation path analysis of agro-morphological traits on yield. Observation of ten agromorphological traits viz. Days to 50\% Flowering, Plant height $(\mathrm{cm}$.), No. of primary

\section{Keywords}

Mustard,

Correlation, Path

analysis, Agro-

morphological

traits.

\section{Article Info}

Accepted:

23 August 2017

Available Online:

10 September 2017 branches, No. of secondary branches, Days to maturity, Length of siliqua, No. of siliqua / plant, No. of seeds/siliqua, 1000 seed weight (gm.), Yield/plant (gm.) were recorded to analyze the data. The seed yield ( $\mathrm{q} / \mathrm{ha}$.) showed highly significant and positive correlation with plant height, Number of siliqua per plant, Number of secondary branches, Number of primary branch. However at phenotypic level days to $50 \%$ flowering, length of siliqua and Number of seeds persiliqua showed non-significant and positive correlation with yield per plant. The correlation coefficient of seed yield $(\mathrm{q} / \mathrm{ha}$ ) showed non-significant but negative correlation with Plant height, Number of primary branches, Number of secondary branches, Days to maturity, Number of siliqua per plant and 1000 seed weight (g) at phenotypic level. Path coefficient analysis revealed that, the highest positive direct effect on seed yield ( $\mathrm{g}$ ) was exhibited by Length of siliqua, days to $50 \%$ flowering and Number of seeds per siliqua. While negative direct effect was recorded among 1000 seed weight, Number of primary branches, Plant height, Number of secondary branches and Number of siliqua per planton seed yield. Number of primary branches, days to maturity, length of siliqua, 1000 seed weight, days to maturity, and 1000 seed weight exhibited negative indirect effect on seed yield.

\section{Introduction}

Indian mustard (Brassicajuncea $2 \mathrm{n}=4 \mathrm{x}=36$ ) and yellow sarson (Brassica compestris) are the important species largely grown as oilseed crop in subtropical and tropical countries. Oilseed brassica is commonly known as rapeseed and mustard and occupy an important position in the rainfed agriculture in India. The oil content of different forms ranges from 30 to 48 per cent (Singh et al., 2014). The mustard oil extracted from mustard seed is the major cooking oil source in northern, eastern and other parts of India. In Asia mustard and rapeseed are chiefly grown in China, India and Pakistan and also grown in other than Asia also i.e. Europe, Canada and USSR. Indian mustard (B. juncea (Linn) Czern and Coss) popularly known as rai, raya or laha is one of the most important oil seed crops of the world and it occupies considerably large average among the Brassica group of oil seed crops. The genus Brassica has six species (B. campestris, $B$. 
oleracea, B. juncea, B. nigra, B. napus, and $B$. carinata) among them first three species are elementary and diploid with $2 \mathrm{n}=16,18$ and 20 chromosomes and other three are tetraploids with chromosome numbers $2 n=34$, 36 and 38.

The nature and magnitude of yield and its traits is essential for further upgrading the yield and formulating better varieties for sustainable production. Therefore the present study was conducted on 220 genotypes of Indian mustard with the objective: (1) to find correlation matrix of agro-morphological traits on yield of mustard crop. (2) To find the Direct and indirect effect of various traits on yield per plant. (3) To find the most appropriate trait to focus in further studies to improve the yield in mustard crop.

\section{Materials and Methods}

A set of 20 diverse genotypes of Indian mustard (Brassica juncea)constituted the experimental materials for the present study was laid out in Randomized Block Design (RBD) with three replications during Rabi season, 2012-13 grow at M.G.C.G.V.V. Chitrakoot, Satna (M.P.). Normal package of cultivation were provided to raise the normal crop. Five competitive plants from each plot were randomly selected and recorded for ten characters viz. Days to $50 \%$ flowering, plant height $(\mathrm{cm})$, Number of primary branches, Number of secondary branches, day to maturity, length of siliqua $(\mathrm{cm})$, Number of siliqua per plant, Number of seed per siliqua, 1000-seed weight (g) and seed yield/plant (g). The mean data were analyzed for different analyses by OPSTAT software.

\section{Results and Discussion}

\section{Phenotypic and genotypic correlations}

The correlation co-efficient analysis helps to determine the nature and degree of relationship between any two measurable characters. It resolves the complex relationships between events into simple forms of association. But the measure of correlation does not consider dependence of one variable over the other. The main purpose of correlation and regression analysis in crop plants is to have detailed understanding of complex characters, such as yield per plant. Correlation coefficients were worked out at genotypic and phenotypic levels for all the ten traits and have been presented in tables 1 and 2 .

In general, genotypic correlations were higher than phenotypic ones in magnitude for all the characters. The character which showed negative association at genotypic level also showed negative association at phenotypic level. The seed yield (q/ha.) showed highly significant and positive correlation with plant height (0.996), No. of siliqua per plant (0.808), No. of secondary branches (0.498), No. of primary branches (0.465), 1000 seed weight (0.996) and length of siliqua (0.808) similarly significant and negative correlation with days to maturity (-0.159), days to $50 \%$ flowering (-0.956) and No. of seeds per siliqua at genotypic level. At phenotypic level day to $50 \%$ flowering (0.154), length of siliqua (0.063) and No. of seeds per siliqua (0.085) showed non-significant and positive correlation with yield per plant.

The correlation coefficient of seed yield (q/ha) showed non-significant but negative correlation with Plant height (-0.185), No. of primary branches (-0.033), No. of secondary branches (-0.192), days to maturity $(-0.129)$, No. of siliqua per plant $(-0.155)$ and 1000 seed weight (g) (-0.29) at phenotypic level. While 1000 seed weight showed positive and non-significant correlation with Day to $50 \%$ flowering (0.46), Plant height (0.24), No. of primary branches (0.64), No. of secondary branches (0.43), days to maturity (0.24), length of siliqua (0.52) and No. of siliqua per 
plant (0.35) at phenotypic level. At genotypic level, correlation coefficient of 1000 seed weight showed positive and non-significant effect on day to $50 \%$ flowering (0.34), Plant height (0.22), No. of primary branches (0.64), No. of secondary branches (0.38), days to maturity (0.54), length of siliqua (0.56) and No. of siliqua per plant (0.36), while No. of seeds per siliqua (-0.08) exhibited negative and non-significant.

The correlation coefficient of number of seed per siliqua exhibited positive and nonsignificant day to $50 \%$ flowering (0.115), plant height (0.020), No. of primary branches (0.244), No. of secondary branches (0.169), days to maturity $(0.135)$ and No. of siliqua per plant (0.311), while Length of siliqua (0.081) exhibited negative and non-significant at genotypic level. The correlation coefficient of No. of seed per siliqua exhibited positive and non-significant day to $50 \%$ flowering (0.045), Plant height (0.010), No. of primary branches (0.227), No. of secondary branches (0.201), days to maturity (0.051), and No. of siliqua per plant (0.248), while Length of siliqua (-0.052) exhibited negative and nonsignificant at phenotypic level. At genotypic level No. of primary branches (0.358) and Plant height (0.444) showed significant and positive correlation with number of siliqua per plant while days to maturity $(-0.194)$ exhibited non-significant and Negative correlation. The other characters like, No. of secondary branches (0.690) significant and Day to $50 \%$ flowering (-0.135) showed negative correlation with No. of siliqua per plant. No. of secondary branches (0.614), plant height (0.426), No. of primary branches (0.284) and length of siliqua (0.284) exhibited non-significant and positive correlation.

\section{Path coefficient analysis}

Path coefficient analysis was used to partition the genotypic and phenotypic correlation coefficients of seed yield with the remaining characters under study into direct and indirect effects are presented in (Table 3).

The genotypic path coefficient analysis was carried out considering 1000 seed weight and seed yield as dependent character and yield attributes as independent characters.

Path coefficient analysis revealed that, the highest positive direct effect on seed yield $(\mathrm{g})$ was exhibited by length of siliqua (0.742), days to $50 \%$ flowering (0.715) and No. of seed per siliqua (0.500). While negative direct effect was recorded in 1000 seed weight ($0.850)$, No. of primary branches (-0.468), Plant height (-0.393), No. of secondary branches (-0.293) and No. of siliqua per plant $(-0.190)$ contributed substantial positive direct effects on Seed yield.

Plant height effected seed yield (0.126) via No. of primary branch (0.106) via No. of seed per siliqua (0.122) and length of siliqua (0.316) via No. of seed per siliqua and days to $50 \%$ flowering, respectively. Days to $50 \%$ flowering (0.611) exerted substantial positive indirect effects on Seed yield.

No. of primary branches (-0.059), days to maturity (-0.056) via length of siliqua ($0.164)$ via 1000 seed weight $(-0.37)$, days to maturity (-0.168) via 1000 seed weight exhibited negative indirect effect on seed yield. However remaining indirect effects were in low magnitude.

The results of present study are in confirmatory with studies of Singh et al., (2016), Lodhi et al., (2016), Kardam and Singh (2014), Mekonnen et al., (2014) who revealed the importance of Plant height, days to maturity, primary branches, secondary branches, seeds per siliqua and other traits effect on seed yield through correlation matrix and path analysis for the development of improved varieties of mustard. 
Table.1 Estimates of genotypic correlation coefficient between10 characters in Indian mustard

\begin{tabular}{|c|c|c|c|c|c|c|c|c|c|c|}
\hline Character & $\begin{array}{c}\text { Days to } \\
50 \% \\
\text { Flowering }\end{array}$ & $\begin{array}{l}\text { Plant } \\
\text { height( } \\
\text { cm.) }\end{array}$ & $\begin{array}{l}\text { No. of } \\
\text { primary } \\
\text { branches }\end{array}$ & $\begin{array}{c}\text { No. of } \\
\text { secondary } \\
\text { branches }\end{array}$ & $\begin{array}{l}\text { Days to } \\
\text { maturity }\end{array}$ & $\begin{array}{l}\text { Length } \\
\text { of } \\
\text { siliqua }\end{array}$ & $\begin{array}{c}\text { No. of } \\
\text { siliqua / } \\
\text { plant }\end{array}$ & $\begin{array}{l}\text { No. of } \\
\text { seeds / } \\
\text { siliqua }\end{array}$ & $\begin{array}{c}1000 \\
\text { seed } \\
\text { weight } \\
(\mathrm{gm} .)\end{array}$ & $\begin{array}{l}\text { Yield/ } \\
\text { plant } \\
\text { (gm.) }\end{array}$ \\
\hline Day to $50 \%$ flowering & 1.000 & -0.321 & 0.125 & -0.010 & -0.252 & -0.220 & -0.135 & 0.115 & 0.34 & $-0.956 * *$ \\
\hline Plant height & & 1.000 & -0.271 & 0.342 & 0.067 & 0.025 & $0.444 *$ & 0.020 & 0.22 & $0.996 * *$ \\
\hline No. of primary branches & & & 1.000 & 0.200 & -0.012 & 0.162 & 0.358 & 0.244 & 0.64 & $0.465^{*}$ \\
\hline No. of secondary branches & & & & 1.000 & -0.050 & -0.204 & $0.690 * *$ & 0.169 & 0.38 & $0.498 *$ \\
\hline Days to maturity & & & & & 1.000 & -0.427 & -0.194 & 0.135 & $0.54 * *$ & -0.159 \\
\hline Length of siliqua & & & & & & 1.000 & 0.238 & -0.081 & 0.56 & 0.285 \\
\hline No. of siliqua / plant & & & & & & & 1.000 & 0.311 & $0.36 * *$ & $0.808 * *$ \\
\hline No. of seeds / siliqua & & & & & & & & 1.000 & -0.08 & -0.295 \\
\hline 1000 seed weight $(\mathrm{g})$ & & & & & & & & & 1.000 & $0.996 * *$ \\
\hline
\end{tabular}

*Significant at $5 \%$ probability level, ${ }^{* *}$ Significant at $1 \%$ probability level.

Table.2 Estimates of phenotypic correlation coefficient between 10 characters in Indian mustard

\begin{tabular}{|c|c|c|c|c|c|c|c|c|c|c|}
\hline Character & $\begin{array}{c}\text { Days to } \\
50 \% \\
\text { Flowering }\end{array}$ & $\begin{array}{l}\text { Plant } \\
\text { height } \\
(\mathrm{cm} .)\end{array}$ & $\begin{array}{l}\text { No. of } \\
\text { primary } \\
\text { branches }\end{array}$ & $\begin{array}{c}\text { No. of } \\
\text { secondary } \\
\text { branches }\end{array}$ & $\begin{array}{l}\text { Days to } \\
\text { maturity }\end{array}$ & $\begin{array}{l}\text { Length } \\
\text { of } \\
\text { siliqua }\end{array}$ & $\begin{array}{l}\text { No. of } \\
\text { siliqua / } \\
\text { plant }\end{array}$ & $\begin{array}{l}\text { No. of } \\
\text { seeds / } \\
\text { siliqua }\end{array}$ & $\begin{array}{c}1000 \\
\text { seed } \\
\text { weight } \\
\text { (gm.) }\end{array}$ & $\begin{array}{l}\text { Yield/ } \\
\text { plant } \\
\text { (gm.) }\end{array}$ \\
\hline Day to $50 \%$ flowering & 1.000 & -0.284 & 0.073 & 0.019 & -0.227 & -0.188 & -0.128 & 0.045 & 0.46 & 0.154 \\
\hline Plant height & & 1.000 & -0.214 & 0.268 & 0.083 & 0.039 & 0.426 & 0.010 & 0.24 & -0.185 \\
\hline No. of primary branches & & & 1.000 & 0.157 & 0.013 & 0.155 & 0.284 & 0.227 & 0.64 & -0.033 \\
\hline No. of secondary branches & & & & 1.000 & -0.067 & -0.187 & 0.614 & 0.201 & 0.43 & -0.192 \\
\hline Days to maturity & & & & & 1.000 & -0.347 & -0.149 & 0.051 & 0.24 & -0.129 \\
\hline Length of siliqua & & & & & & 1.000 & 0.220 & -0.052 & 0.52 & 0.063 \\
\hline No. of siliqua / plant & & & & & & & 1.000 & 0.248 & 0.35 & -0.155 \\
\hline No. of seeds / siliqua & & & & & & & & 1.000 & 0.020 & 0.085 \\
\hline 1000 seed weight $(\mathrm{g})$ & & & & & & & & & 1.000 & -0.29 \\
\hline
\end{tabular}


Table.3 Direct and indirect effects for different characters on seed yield per plant at phenotypic level in Indian mustard

\begin{tabular}{|c|c|c|c|c|c|c|c|c|c|c|}
\hline Characters & $\begin{array}{c}\text { Days to } \\
50 \% \\
\text { Flowering }\end{array}$ & $\begin{array}{c}\text { Plant } \\
\text { height }(\mathrm{cm})\end{array}$ & $\begin{array}{l}\text { No. of } \\
\text { primary } \\
\text { branches }\end{array}$ & $\begin{array}{c}\text { No. of } \\
\text { secondary } \\
\text { branches }\end{array}$ & $\begin{array}{l}\text { Days to } \\
\text { maturity }\end{array}$ & $\begin{array}{l}\text { Length of } \\
\text { siliqua } \\
(\mathrm{cm})\end{array}$ & $\begin{array}{l}\text { No. of } \\
\text { siliqua / } \\
\text { plant }\end{array}$ & $\begin{array}{l}\text { No. of } \\
\text { seeds / } \\
\text { siliqua }\end{array}$ & $\begin{array}{c}1000 \\
\text { seed } \\
\text { weight } \\
(\mathrm{gm})\end{array}$ & $\begin{array}{l}\text { Correlation } \\
\text { of yield with } \\
\text { differed } \\
\text { characters }\end{array}$ \\
\hline $\begin{array}{l}\text { Day to } 50 \% \\
\text { flowering }\end{array}$ & 0.715 & 0.126 & -0.059 & 0.003 & -0.056 & -0.164 & 0.026 & 0.057 & -0.37 & 0.611 \\
\hline Plant height & -0.229 & -0.393 & 0.127 & -0.100 & 0.015 & 0.019 & -0.084 & 0.010 & -0.23 & -0.659 \\
\hline $\begin{array}{l}\text { No. of primary } \\
\text { branches }\end{array}$ & 0.090 & 0.106 & -0.468 & -0.059 & -0.003 & 0.120 & -0.068 & 0.122 & -0.69 & -0.228 \\
\hline $\begin{array}{l}\text { No. of secondary } \\
\text { branches }\end{array}$ & -0.007 & -0.134 & -0.094 & -0.293 & -0.011 & -0.151 & -0.131 & 0.085 & -0.41 & -0.777 \\
\hline Days to maturity & -0.180 & -0.026 & 0.006 & 0.015 & 0.223 & -0.317 & 0.037 & 0.067 & -0.68 & -0.343 \\
\hline Length of siliqua & -0.158 & -0.010 & -0.076 & 0.060 & -0.095 & 0.742 & -0.045 & -0.040 & -0.61 & 0.316 \\
\hline $\begin{array}{l}\text { No. of siliqua / } \\
\text { plant }\end{array}$ & -0.096 & -0.174 & -0.168 & -0.202 & -0.043 & 0.177 & -0.190 & 0.155 & -0.48 & -0.689 \\
\hline $\begin{array}{l}\text { No. of seeds / } \\
\text { siliqua }\end{array}$ & 0.082 & -0.008 & -0.114 & -0.050 & 0.030 & -0.060 & -0.059 & 0.500 & 0.08 & 0.330 \\
\hline $\begin{array}{l}1000 \text { seed weight } \\
\text { (g) }\end{array}$ & 0.025 & -0.008 & -0.030 & -0.011 & 0.035 & 0.042 & -0.026 & -0.004 & -0.850 & -0.063 \\
\hline
\end{tabular}

Residual factor $=0.279$; Direct effects on main diagonal (bold figures) 
In general, genotypic correlations were higher than phenotypic ones in magnitude for all the characters. The character which showed negative association at genotypic level also showed negative association at phenotypic level. The seed yield showed highly significant and positive correlation with plant height, seed yield per plat, No. of secondary branch, and No. of primary branch with days to maturity and days to $50 \%$ flowering at genotypic level.

Path coefficient analysis revealed that, the highest positive direct effect on Seed yield was exhibited by Length of siliqua, days to $50 \%$ flowering and No. of seed per siliqua. Plant height via No. of primary branch via No. of seed per siliqua and length of siliquavia No. of seed per siliqua and days to $50 \%$ flowering, respectively showed indirect effect on seed yield of crop which is economic yield. Based on correlation and path study characters like seed yield per plant, No. of primary branches, No. of secondary branches, plant height, length of siliqua, No. seed per siliqua and 1000 seed weight are major yield contributing traits and keen observation and breeding based on these traits can improve yield of mustard effectively.

\section{References}

Kardam, D.K., and Singh, V.V. 2014.Correlation and path analysis in Indian mustard (Brassica juncea (L.) Czern \& Coss) grown under rainfed condition. J. S. Arom. crops, 14(1).

Lodhi, B., Avtar, N.T.R. and Singh, A. 2016. Genetic variability, association and path analysis in Indian mustard (Brassica juncea). J. Oils. Bras., 1(1): 26-31.

Mekonnen, T.W., Wakjira, A. and Genet, T. 2014. Correlation and path coefficient analysis among yield component traits of Ethiopian mustard (Brassica carinata a. Brun) at Adet, Northwestern, Ethiopia J. Plant Sci, 2(2): 89-96.

Singh, A., Shahi, S., Katiyar, R.K., Gaur, S. and Jain, V. 2014. Asia Pacific.

Singh, M., Shrivastav, R.L., Lalta, P. and Dixit, R.K. 2003. Correlation and path analysis in Indian mustard (B. juncea (L.) Czern and Coss). Adv. Pl. Sci., 16(1): 311-315.

Singh, M., Tomar, A., Mishra, C.N. and Srivastava, S.B.L. 2016. Genetic parameters and character association studies in Indian mustard. J. Oils. Bras, 1(1): 35-38.

\section{How to cite this article:}

Ravindra Singh Solanki, Pawan Kumar, S.P. Mishra and Ramgiry, S.R. 2017. Contribution of Agro-Morphological Traits in Seed Yield of Indian mustard (Brassica juncea L. Czern \& Coss) Germplasm under Rainfed Condition. Int.J.Curr.Microbiol.App.Sci. 6(9): 2281-2286. doi: https://doi.org/10.20546/ijcmas.2017.609.279 